\title{
Наталія Литвин
}

Член Всеукраїнської асамблеї докторів наук з державного управління, старший викладач кафедри публічного адміністрування, Міжрегіональна Академія управління персоналом, м. Київ, Україна, e-mail:phd.nata@gmail.com

https://orcid.org/0000-0003-0120-3443

\section{ШЛЯХИ УДОСКОНАЛЕННЯ МІСЦЕВОГО САМОВРЯДУВАННЯ В УКРАÏHI}

\begin{abstract}
Анотація. Невелика ефективність вирішення питань місцевого значення органами місцевого самоврядування зумовлюється нехваткою ресурсів на виконання наданих їм повноважень. В статті представлено напрями щодо удосконалення українського місцевого самоврядування 3 метою соціально-економічного розвитку. Основна увага приділялась питанням фінансового та організаційного забезпечення органів місцевого самоврядування.
\end{abstract}

Ключові слова: органи місцевого самоврядування, фінансова децентралізація, фінансове забезпечення розвитку територіальних громад.

\section{Nataliia Lytvyn}

Member of the Ukrainian Assembly of Doctors of Science in Public Administration, Senior Lecturer of the Department of Public Administration, Interregional Academy of Personnel Management, Kyiv, Ukraine, e-mail:phd.nata@gmail.com https://orcid.org/0000-0003-0120-3443

\section{WAYS OF IMPROVING LOCAL GOVERNMENT IN UKRAINE}

\begin{abstract}
The low efficiency of local self-government in resolving issues of local importance is due to the lack of resources to fulfill the powers granted to them. Therefore, the article presents directions for improving Ukrainian local selfgovernment for socio-economic development. The main attention was paid to the issues of financial and organizational support of local self-government bodies.

Keywords: local governments, financial decentralization, principles of financial provision of development of territorial communities.
\end{abstract}

Постанова проблеми. Наразі в Україні більшість об'єднаних територіальних громад залишаються дотаційними. Фінансові проблеми 
місцевого самоврядування негативно відбиваються, як на громадянах, так i на державі в цілому. Тому, органам місцевого самоврядування необхідне підвищення незалежності у розпорядженні власними ресурсами, що вимагає більш широкого підходу до управління місцевими фінансами та адміністративно-територіальною одиницею.

Аналіз досліджень і публікацій. У вітчизняній науці питання фінансового забезпечення місцевого самоврядування розглядають такі вчені, як: В. Базилевич, О. Василик, О. Кириленко, В. Опарін, С. Юрій та ін. Загалом, цінність їхніх праць полягає у забезпеченні фінансової самостійності органів місцевого самоврядування і збалансованого соціальноекономічного розвитку регіонів. Проте окремі питання фінансового забезпечення місцевих органів влади потребують подальшого дослідження.

Мета статті полягає у визначенні шляхів щодо подальшого розвитку та ефективного функціонування органів місцевого самоврядування.

Виклад основного матеріалу. В Україні більшість об'єднаних територіальних громад є дотаційними, а отже вони не в змозі функціонувати автономно. На це вказує те, що наразі в Україні є багато міст та сіл, які не в змозі належним чином надавати якісні соціальні послуги громадянам та власними силами утримувати муніципальні установи. А також, через брак ресурсів місцеві органи влади не мають можливості розвивати комунальне господарство та реалізовувати важливі стратегічні інфраструктурні проекти. Особливо це стосується сільських територій (в яких відсутні туристичні і курортні зони) в яких значними темпами скорочується місцеве населення й спадає місцева економіка.

Тому, сучасна система влади та управління потребує модернізації. Необхідно удосконалити систему територіальної організації влади 3 метою підвищення ефективності управління суспільним розвитком на відповідній території [2].

Аби впоратися 3 наявними проблемами багатьох територіальних громад необхідне їхнє співробітництво та партнерство. Адже, завдяки спільним зусиллям та фінансуванню, можливо вирішувати багато нагальних проблем, реалізовувати взаємовигідні проекти та загалом покращити економічний стан регіонів.

Досвід вказує, що об'єднання та співробітництво між територіальними громадами набирає все більше популярності. Можна побачити, що з кожним роком зростає кількість об'єднаних територіальних громад, котрі об'єднавши зусилля та ресурси вирішують питання соціального, комунального та житлового забезпечення. Проте, нинішній стан місцевого самоврядування потребує ефективних стратегій та чіткого дотримання і виконання низки правил й заходів, які спрямовані на економічний розвиток територій.

Для того, щоб об'єднання сприяло значним позитивним результатам, територіальним громадам під час об'єднання необхідно дотримуватися чіткого ряду правил. Найважливіше правило полягає в тому, що об'єднання повинно відбуватися на певних територіях. Тобто, об'єднання 
територіальних громад має бути логічним, а також воно повинно відбуватися у рамках області. Слід зазначити, що хаотичне об’єднання територіальних громад без відсутності заздалегідь підготовленого плану та стратегії створює реальну загрозу, як для самих громад, так і для держави загалом.

Після виконання чіткого ряду правил центральний уряд зможе надати низку привілей, таких, як перехід на прямі стосунки із державним бюджетом, закріплені податки, додаткові надходження до місцевих бюджетів на розвиток територій, інфраструктури тощо.

Після об'єднання місцеві бюджети переводяться на прямі міжбюджетні відносини 3 державним бюджетом, а отже, фінансування стає прямим $[3,4]$. Саме, прямі міжбюджетні відносини та посилення фінансової децентралізації можуть подолати дефіцит фінансових ресурсів місцевих бюджетів, а також забезпечити ефективність діяльності місцевої влади й їхній подальший розвиток.

Слід зазначити, що об'єднання фінансово спроможних територіальних громад із біднішими громадами дозволяє справедливо розподіляти фінансові ресурси та активно розвивати території.

Зокрема, об’єднання позитивно впливає на архітектурно-будівельну сферу, адже об'єднаним територіальним громадам передається частина повноважень, завдяки яким легше вводити в експлуатацію об'єкти та споруди. Все це значно спрощує відповідні процедури та стимулює територіальні громади в інфраструктурному розвитку, який дуже важливий, як для самих громад, так і для потенційних інвесторів.

Необхідно розуміти, що правильне планування територій створює можливості для ефективного використання земельних ресурсів. Не так важливо в якій власності (державній, муніципальній, приватній) території, головне аби землі використовувалася за своїм цільовим призначенням й використовувалася якомога ефективніше. Розумне використання земельних ресурсів створює можливості для економічного розвитку територій.

Проте, для того, щоб територіальні громади безперешкодно об'єднувались та співпрацювали, необхідно вирішити проблему із невизначеністю меж територій. Адже, через брак інформації про об'єкти та земельні ресурси територіальні громади не можуть планувати свою діяльність та ефективно використовувати земельні ресурси. Тому, необхідно забезпечити місцеві органи влади відповідною інформаційною базою, необхідною для об'єднання та співробітництва 3 іншими територіальними громадами.

Зокрема, органи місцевого самоврядування мають бути зацікавлені у зменшенні кількості адміністративно-територіальних одиниць. В той час, як центральний уряд має виділити фінансові ресурси 3 державного бюджету на проведення інвентаризації та розмежування земель. Чітке розмежування територій та повна інформаційна база про об'єкти розташованих на них, підвищать ефективність управління та використання земельних ресурсів, оскільки органи місцевої влади будуть мати правову основу для 
розпорядження ними.

Варто брати до уваги досвідченість керівників територіальних громад у сфері стратегічного планування та управління. Адже, керівникам місцевої влади необхідно чітко визначати мету, стратегію та засоби, які необхідні для подолання наявних проблем територіальних громад. Також, кожен керівник громади повинен активно шукати нові можливості для наповнення місцевого бюджету з метою розвитку територій.

Об'єднання територіальних громад повинно базуватися на потребах i можливостях, адже напрямків для співробітництва може бути досить багато, починаючи iз соціальних проектів, закінчуючи економічним розвитком. Тому, координоване співробітництво між територіальними громадами дає низку можливостей у багатьох сферах, які необхідно ефективно використовувати аби нова адміністративна одиниця була більш потужною та спроможною.

Зокрема, об'єднання територіальних громад та їхнє активне співробітництво дозволяє не тільки економити ресурси, а й підвищує ефективність їх використання. Тож, процес об'єднання i $\epsilon$ ефективним інструментом місцевого економічного розвитку завдяки якому, можливо, упорядкувати планування територій та сумісно розвивати соціальну й економічну сфери.

Наразі процес об'єднання та співробітництва територіальних громад триває та демонструє позитивні результати. Тому, на даному етапі вкрай важливо оперативно виявляти й аналізувати помилки, які виникають під час об'єднання. Слід зауважити, що проблеми, які виникають під час об'єднання необхідно не тільки виявляти, а й враховувати та робити все можливе для їхнього уникнення.

Отже, спільною роботою, мотивацією та зусиллями можливо ефективно використовувати земельні, природні та фінансові ресурси. А також, завдяки об'єднанню та співробітництву, можливо, зменшити кількість дотаційних територіальних громад, що в свою чергу підвищить економічне становище територій та держави загалом.

Центральний уряд повинен бути зацікавлений в тому, щоб в нашій країні існувало ефективне місцеве самоврядування, яке має бути однією із фундаментальних цілей спрямованих на задоволення потреб населення. Щоб найкращим чином задовольнити очікування місцевого населення, діяльність місцевої влади повинна бути ефективною, результативною та не корумпованою.

Враховуючи позитивний зарубіжний та історичний вітчизняний досвід, спроможність місцевого самоврядування всіх територіальних громад України може бути забезпечена лише через наділення їх достатньою базою у фінансовому, інфраструктурному та кадровому аспектах [5,С. 42-47].

Досягнення мети стимулювання ефективності функціонування органів місцевого самоврядування можливе лише в разі втілення комплексних заходів спрямованих на покращення умов управління та функціонування. 
Першочергово необхідна зміна культури функціонування органів місцевого самоврядування. Місцеві органи влади повинні бути спрямовані на культуру досягнення результатів, проте це вимагає деяких організаційних змін.

Для того, щоб модернізувати сучасну українську систему місцевого самоврядування та підвищити спроможність територій необхідно залучати інвестиційні та інноваційні ресурси. Одним із швидких способів розвитку регіонів $є$ модернізація нинішньої системи вільних економічних зон. Особливо це стосується фінансово слабких та дотаційних територій України. Саме ці території $\epsilon$ пріоритетні для залучення, як українських так i закордонних інвестиційних, інноваційних та технологічних ресурсів.

Наразі в нашій країні на шляху із залученням закордонних інвестицій існує багато проблем, починаючи від інституційного середовища, завершуючи законодавчою базою. Тому, завдання центрального уряду має полягати у створенні сприятливого інвестиційного клімату, який швидкими темпами може сприяти росту економіки регіонів та держави загалом. Проте, це потребує з боку держави відповідних законодавчих та організаційних змін.

Закордонний досвід вказує, що розвиток багатьох країн, характеризується значною територіальною неоднорідністю та відмінністю в інтенсивності господарської діяльності. 3 практики більшості країн, котрі розвиваються ключовим елементом із залучення іноземного капіталу є саме території з преференційним інвестиційним режимом.

Саме тому, рекомендується скористатися досвідом розвинених країн та модернізувати нинішню українську систему вільних економічних зон на окремих локальних територіях, тобто на тих територіях в яких фінансові показники на досить низькому рівні.

Особливістю цих зон $є$ те, що їхнє формування базується переважно на залученні іноземних інвестицій, а діяльність здійснюється на преференційних умовах типу пільгового оподаткування. Значною мірою ефективність функціонування вільних економічних зон залежить від погодження інтересів інвесторів, держави та територій. Для інвесторів важливий прибуток, для держави - надходження коштів у бюджет країни, для територіальних громад нові робочі місця, регіональний розвиток та надходження фінансових ресурсів у місцеві бюджети. Без врахування вище перелічених інтересів існування вільних економічних зон є проблематичним.

Для того, щоб залучити іноземних інвесторів першочергово необхідне визначення пріоритетних територій країни, тобто найбільш депресивних територій в яких значними темпами спадає місцева економіка. А також, слід проаналізувати наявність інфраструктури, системи оподаткування, підготовка кадрів тощо.

Кожна країна, метою якої є розвиток економіки, намагається залучити на свої території закордонних інвесторів, заохочуючи їх відповідними фінансовими механізмами. Власне вільні економічні зони і є одним із таких механізмів, стратегічне завдання яких полягає, як у залученні інвестицій та інновацій, так і в створенні нових робочих місць, модернізації виробництва, 
активізації підприємницької діяльності, стимулюванні регіонального розвитку, впровадженні нових ефективних технологій тощо.

Зокрема, вільні економічні зони можна вважати інструментом регіональної політики. Прискорений регіональний розвиток $\epsilon$ головним завданням багатьох країн (з використанням їхніх власних ресурсів будь-то сировинних, природних або трудових) у яких спостерігаються депресивні регіони. Вільні економічні зони повинні створюватись у тих регіонах країни, де без додаткових фінансових пільг закордонним компаніям не вигідно вкладати свої інвестиції. Під вільними економічними зонами необхідно розуміти виділення частини території або регіону, яка має повну свободу у сфері господарських питань, 3 пільговими умовами діяльності. Це має стосуватися, як місцевих українських, так і закордонних компаній.

Наразі в Україні створені вільні економічні зони не відіграють важливої ролі із залучення закордонних інвестицій. Від початку їхнього функціонування до них було залучено вкрай мало закордонних інвестицій. Це обумовлюється тим, що наразі існує непрозорий процес із надання пільг, відсутність чіткого механізму та брак державного контролю. Як результат, реалізація можливостей вільних економічних зон в Україні не набула належного застосування.

Для вирішення цієї проблеми необхідна нова концепція вільних економічних зон, яка б спиралася на низку засад:

- залучення інвестицій в пріоритетні галузі (слаборозвинені промислові регіони, наукову та дослідну діяльність);

- завершення процесу децентралізації влади, яка забезпечить передачу повноважень від держави на рівень місцевих органів влади;

- удосконалення чинної нормативно-правової бази щодо гнучкої диференційованої системи 3 надання пільг, як для українських, так i для закордонних інвесторів;

- розроблення державних гарантій для інвесторів.

Отже, для того, щоб територіальні громади мали достатні фінансові ресурси, а також 3 метою подолання відставання розвитку українських територій необхідно створити всі необхідні умови для залучення, як українських так і закордонних інвестиційних, інноваційних та технологічних ресурсів.

Підтримка центрального уряду $є$ основним елементом для розвитку територій та залучення інвестицій. Тому, завдання держави має полягати в тому, щоб створити всі необхідні умови та гарантії для залучення українського та іноземного капіталу. Адже, головна ідея вільних економічних зон полягає в тому, щоб розвинути фінансово слабкі території. Тому, залучення до депресивних територій інвестиційних та інноваційних ресурсів сприятиме їхньому швидкому економічному розвитку.

На сьогодні в сфері місцевого самоврядування $\epsilon$ актуальними дослідження комунікаційних процесів взаємодії місцевої влади із громадськістю, оскільки в сучасних умовах комунікація $є$ важливим 
чинником суспільних відносин, а також важливим елементом громадського контролю [1].

За останні роки в Україні завдяки втіленим реформам відбуваються суттєві зміни у відносинах місцевої влади з громадськістю. Органи місцевої влади виступають, як адміністративні структури, котрі надають публічні послуги місцевому населенню. Тому, нинішня система комунікації повинна полягати у вдосконаленні концепції управління суспільною інформацією й забезпечення ефективної взаємодії з населення. Адже, саме інформація й координована комунікація виступають основою процесу надання послуг громадянам.

Варто зазначити, що саме використання сучасних інформаційнокомунікаційних технологій може забезпечити ефективну взаємодію між місцевою владою i громадськістю. А також, комунікація $\epsilon$ важливим елементом в прийнятті та реалізації важливих для територіальних громад рішень. Адже, Конституційне право громадян на публічну інформацію має реалізовуватися повною мірою, особливо на рівні місцевих органів влади. Тому, що саме місцева влада надає соціальні послуги місцевому населенню, так як вона є найбільш наближеною гілкою влади до громадян. Саме тому, до функцій органів місцевого самоврядування мають входити контроль якості 3 наданих публічних послуг.

На сьогодні місцеві органи влади потребують подальшого розвитку інформаційно-комунікаційних технологій. Тому, що саме комунікація $\epsilon$ інструментом вдосконалення відносин місцевих органів влади із громадськістю, а також завдяки якому підвищується ефективність самоорганізації населення в системі трансформаційних процесів державного управління. Тож, завдання органів місцевого самоврядування має полягати у роз'яснені населенню про методи залучення громадян до процесу управління територіальною громадою. Зокрема, з боку місцевої влади необхідно надати мешканцям територіальних громад всі необхідні інструменти.

Органи місцевого самоврядування повинні забезпечувати підзвітність основних показників населенню, а також мати термін часу для розгляду проектів та стратегій. Відкритий доступ до публічної інформації дозволить встановити довіру між місцевою владою та громадянами, а також послідовно виконувати заздалегідь визначені цілі.

У відкритому доступі для громадян має бути інформація про діяльність органів місцевої влади, посадових осіб, бюджетні показники та стратегічні цілі разом з очікуваними. Усі вищезазначені показники мають бути у відкритому доступі для громадян та опубліковані на офіційному веб-сайті муніципалітету, доступні на мобільних пристроях і додатках у режимі онлайн, а також розміщені в інформаційному бюлетені органів місцевого самоврядування. Проведення он-лайн голосування (визначення пріоритетних проектів, стратегії, обрання депутатів) дозволить економити місцеві ресурси, час населення, спростить процедуру голосування громадян 3 особливими потребами, а також це буде виступати дієвим інструментом під час 
карантинних заходів тощо. Слід зазначити, що дуже важливо аби публічна інформація була не тільки доступною, а й зрозумілою для кожного громадянина. Таким чином, кожен громадянин буде мати змогу контролювати діяльність місцевої влади й слідкувати за рівнем досягнення заздалегідь встановлених цілей.

Завдяки відкритому доступу до публічної інформації підвищиться прозорість діяльності органів місцевої влади, зменшиться корупція на місцях, зросте довіра населення до місцевої влади, а також це буде дієвим інструментом державного контролю. А також, важливо аби кожна територіальна громада мала свою стратегію, яка повинна бути введена в дію. Заплановані заходи 3 реалізації стратегій повинні відображатися в запланованій діяльності муніципалітету.

Слід зазначити, що важливу роль відіграє не тільки досвідченість а й відповідальність керівників місцевих установ у стратегічному плануванні та управлінні. Тому, що спосіб, яким керує голова місцевого органу, багато в чому залежить від поставлених ним цілей. Саме керівник повинен мати своє бачення майбутнього керованої установи, проте, це бачення має бути вбудовано в потреби суспільства. Керівник повинен враховувати специфіку території, якою він керує, а також визначати пріоритетні напрями розвитку. Голова місцевої установи та його організаційні підрозділи повинні планувати й управляти стратегічно, а також нести відповідальність за свою діяльність перед громадянами та державою. Тож, необхідно заздалегідь встановлювати цілі, котрі вбудовані в потреби суспільства, а також необхідно максимально залучати місцеве населення у визначенні пріоритетних стратегій.

Варто зазначити, що територіальним громадам необхідно розробляти й реалізовувати комунальну та інфраструктурну стратегії. Адже, саме наявність розвиненої інфраструктури і є основним елементом для залучення іноземного капіталу. Згуртованістю цих стратегій повинна опікуватися місцева влада. Цілі та рівень їхнього досягнення також повинні бути у відкритому доступі на офіційному веб-сайті муніципалітету.

Щоб уникнути виникнення можливих суперечностей між стратегічними цілями, планування має бути погоджено. Координоване встановлення цілей та нагляд за їхнім виконанням $є$ основним елементом системи управління. Керівники органів місцевого самоврядування повинні полягати у підпорядкуванні окремих організаційних підрозділів, котрі виконують завдання самоврядування. Тому роль керівників вкрай важлива, щоб процеси планування (встановлення цілей) координувалися й у такий спосіб забезпечували організаційні підрозділи необхідними інструментами. Визначальна роль населення полягає в тому, аби мешканці територіальних громад брали активну участь у прийнятті важливих для громад рішень й цілей, а також громадяни повинні модерувати цей процес.

Зокрема, важливим елементом контролю має виступати саме якість наданих місцевою владою для громадян публічних послуг. Адже, місцеві органи влади здійснюють завдання від імені держави, тому ці завдання 
повинні підлягати оцінці. Саме вимірювання якості наданих публічних послуг і буде визначальним кроком до процесу планування, який означає, що цілі місцевих органів влади повинні поєднуватися 3 цілями центрального уряду. Тож, послуги, які надаються громадянам повинні підлягати оцінці, а діяльність місцевої влади повинна бути ефективною. Основна увага законодавця має полягати в тому, щоб оцінити цю ефективність. Оцінка якості має стосуватися обов'язкових державних послуг, які надаються органами місцевого самоврядування громадянам.

Щоб, мати можливість вимірювати ефективність діяльності органів місцевого самоврядування, необхідно встановити єдині методи щодо вимірювання якості державних послуг, які надаються населенню кожним органом влади. Проте, стандартизація державних послуг та застосування єдиної методології щодо вимірювання якості наданих послуг потребують створення відповідних організаційних та правових норм на національному рівні. Зокрема, створення такої системи вказує на необхідність стандартизації основних державних послуг, які надаються громадянам та визначення ключових показників для їхнього вимірювання.

Стандартизація державних послуг повинна призвести до встановлення мінімальних стандартів обов'язкового характеру. Основою для створення цих стандартів мають бути критерії вартості та якості публічних послуг. Водночас важливо правильно визначити показники ефективності та особливо доступності публічних послуг, які надаються населенню. Ці показники мають бути невід'ємним елементом Національної системи моніторингу з надання державних послуг.

Варто зауважити, що чітке розмежування повноважень та визначення мінімальної фінансової забезпеченості для органів місцевого самоврядування дозволить уникнути багатьох конфліктів й якісно вирішувати питання місцевого значення. Проте, органи місцевого самоврядування повинні нести значну відповідальність за свою діяльність, а також відповідати за іiі ефективність перед громадянами та центральним урядом.

Особливо актуальним питанням в контексті фінансової децентралізації $\epsilon$ високий ризик неефективного використання фінансових ресурсів місцевих бюджетів та недосконала система контролю за внутрішньою діяльність місцевих органів влади.

Нинішній етап місцевого самоврядування свідчить про те, що в багатьох об'єднаних територіальних громадах відсутній фінансовий орган, основною функцією якого є організація та координація бюджетного процесу. Органи місцевого самоврядування, які прагнуть розвивати свої території та бути незалежними мають бути зацікавленні у створенні окремого фінансового органу (відокремленого як юридична одиниця). Адже, даний орган має більший перелік повноважень, щодо ефективного та цільового використання бюджетних ресурсів, й завдання якого полягає у здійсненні внутрішнього аудиту. Під час створення фінансового органу основною умовою має бути те, що керівники, котрі будуть очолювати цей орган мають бути 
висококваліфіковані, адже на їхні плечі лягає значна відповідальність щодо ефективного фінансового менеджменту.

На сьогодні в багатьох об’єднаних територіальних громад застосовуються відповідні процедури, які можна вважати елементами внутрішнього контролю. Але проблема полягає в тому, що більшість органів місцевого самоврядування не мають комплексного та систематичного підходу щодо внутрішнього контролю. Тому виникає необхідність в його подальшому вдосконаленні шляхом розробки та впровадження відповідних документів, що врегульовують управлінські процеси на рівні місцевої влади. Слід зазначити, що цей процес дуже складаний, тому він потребує значної підтримки з боку центрального уряду.

Для того, щоб збільшити фінансову спроможність об'єднаних територіальних громад автор розробив оригінальну концепцію, метою якої удосконалення місцевого самоврядування та прискорення завершення процесу фінансової децентралізації. Запропонована комплексна концепція щодо економічного розвитку територій, можливо, зробить вирішальний внесок у ліквідацію нинішніх дотаційних територій країни.

Концепція «Сотні об’єднаних територіальних громад - єдина країна», метою якої є створення економічно розвинених об'єднаних територіальних громад. Дана модель орієнтована аби дотаційні об’єднані територіальні громади мали змогу активно розвивати підприємництво на своїх територіях, шляхом створення привабливих податкових умов. Адже, наскільки будуть розвинені територіальні громади, настільки буде сильна з економічної точки зору наша держава.

Дана концепція сформована таким чином, щоб створити ефективні та дієві програми пільгового оподаткування на тих територіях, які досі залишаються дотаційними та в яких відсутні привабливі умови для ведення бізнесу.

Для даної концепції першочергово необхідно розробити програму пільгового оподаткування, яка має стосуватися нових, як закордонних так i українських підприємств. Ставка податків безпосередньо повинна залежати від виду господарської діяльності. Тобто, мета даної програми полягає в тому, аби дотаційні об'єднані територіальні громади на свій розсуд знижували місцеві податкові ставки в залежності від виду господарської діяльності або навіть взагалі на деякий час звільняли підприємства від сплати податків. Звичайно ж, все це потребує з боку центрального уряду багатьох організаційних та законодавчих змін.

Слід зазначити, що вкрай важливою є координація та сумісна співпраця під час втілення масштабних проектів (будь то будівництво великих підприємств або важливих стратегічних інфраструктурних споруд), котрі займають територію декількох об'єднаних територіальних громад. Для ефективного підприємницького та економічного розвитку необхідна співпраця, яка повинна полягати у взаємовигідній допомозі з боку кожної об’єднаної територіальної громади. Тобто, кожна об’єднана територіальна 
громада, яких пов'язує спільний взаємовигідний проект повинні діяти та співпрацювати комплексно, координуючи один одного. А також, при необхідності робити певні винятки у вигляді поступок тощо.

Водночас, центральний уряд повинен розробити державну програму стимулювання розвитку приватного підприємництва на слаборозвинених територіях країни. До цієї державної програми необхідно залучати ті об'єднані територіальні громади, в яких фінансові показники на досить низькому рівні, тобто найбільш дотаційні території.

Об’єднані територіальні громади повинні надавати запит до центральної влади щодо внесення їхніх територій до державної програми стимулювання розвитку приватного підприємництва на пільгових податкових умовах. Натомість, завдання уряду має полягати у тому, щоб розрахувати доцільність запуску програми на цих територіях виходячи з їхніх основних фінансових показників. Якщо доцільність виправдана, центральний уряд включає відповідну територію до державної програми та надає всі привілеї у вигляді зниження податкових ставок або навіть взагалі на визначений термін прибирає їх. Тобто, уряд на заздалегідь визначений період створює відповідні пільгові умови або безподаткові території, метою яких $\epsilon$ запуск підприємницької діяльності та розвиток інфраструктури в об'єднаних територіальних громадах. Зокрема, дана програма стосується тих податків, які безпосередньо спрямовуються до державного бюджету.

Звісно ж, державна програма буде діяти лише на найбільш економічно нерозвинених територіях та у певний проміжок часу, або поки ці території не вийдуть на самодостатній фінансовий рівень. Тобто, найбільш дотаційні об’єднані територіальні громади будуть мати змогу користуватися всіма важелями для економічного розвитку територій до тих пір, поки вони не вийдуть на відповідний рівень. Після того, як об'єднані територіальні громади досягнуть самодостатнього фінансового рівня, центральний уряд виключає ці території із даної програми.

На думку автора, дана державна програма є досить ефективною 3 тієї точки зору, що якщо навіть певній території надати фінансові ресурси, то зрозуміло що сплата податків значно знизить їхню початкову суму.

Зокрема, вищезазначена концепція унеможливлює існування дотаційних об’єднаних територіальних громад шляхом стимулювання розвитку приватного підприємництва. А також, запропонована концепція буде рушійним елементом 3 реалізації важливих стратегічних інфраструктурних проектів.

Слід зазначити, що координація та співпраця між об’єднаними територіальними громадами та центральною владою будуть вирішальними елементами в прийнятті та реалізації важливих стратегічних рішень. Адже місцева влада має значні важелі, які необхідні для розвитку підприємництва та територій, зокрема. 3 точки зору держави, уряд також буде приймати участь у економічному розвитку територій, проте це вимагає певних поступок. Адже, в результаті економічний розвиток депресивних територій, 
котрі будуть реалізовуватися відокремленим державним проектом, призведе до економічного зростання держави загалом.

Ефективність функціонування даної концепції значно залежить від погодження інтересів підприємств, об'єднаних територіальних громад та центрального уряду. Адже, важливою умовою для розвитку приватного підприємництва є саме наявність привабливих умов для ведення бізнесу.

Висновки. Економічний розвиток територій та ефективне місцеве самоврядування можливе лише в разі вживання комплексних заходів. Першочергово це стосується нормативно-правових змін з боку центрального уряду, оскільки органи місцевого самоврядування мають законні обмеження в обсягах і формах своєї діяльності.

Залучення до депресивних територій інвестицій дозволить прискорити регіональний розвиток, тому необхідно створити відповідний інвестиційний клімат та розробити державні гарантії для інвесторів. Слід зазначити, що залучення до українських територій інвестицій дозволить впровадити нові технології, модернізувати інфраструктуру, активізувати підприємницьку діяльність тощо.

\section{Лimepamypa:}

1. Каплан Ю. Механізм прямого народовладдя на місцевому рівні : стан та напрями підвищення ефективності [Електронний ресурс]. - Режим доступу : http: //old.niss.gov.ua/Monitor/Juli08/10.htm - Заголовок з екрану.

2. Новікова О. Основні напрями реформування та територіальної організації влади в Україні / О. Новікова // Національна академія державного управління при Президентові України Дніпропетровський регіональний інститут державного управління. [Електронний pecypc]. — Режим доступу : http://www.dridu.dp.ua/vidavnictvo/2012/2012_01(12)/12nooovu.pdf.

3. Про добровільне об'єднання територіальних громад : закон України від 5 лютого 2015 p. № 157-VIII. - Режим доступу : http://zakon4.rada.gov.ua/laws/show/157-19.

4. Про місцеве самоврядування в Україні : закон України від 21 травня 1997 р. № 280/97BP. - Режим доступу : http://zakon4.rada.gov.ua/laws/show/280/97-вр.

5. Торгонська А.В. Реформування органів місцевого самоврядування в Україні / А.В. Торгонська // Право і суспільство : Зб.наук.пр. №1, частина 2/2017. С. 42-47.

\section{References:}

1. Kaplan, Yu. (n.d.). Mekhanizm priamoho narodovladdia na mistsevomu rivni : stan ta napriamy pidvyshchennia efektyvnosti [The mechanism of direct democracy at the local level: the state and directions of improving efficiency]. old.niss.gov.ua. Retrieved from http://old.niss.gov.ua/Monitor/Juli08/10.htm [in Ukrainian].

2. Novikova, O. (2012). Osnovni napriamy reformuvannia ta terytorialnoi orhanizatsii vlady $\mathrm{v}$ Ukraini [The main directions of reform and territorial organization of power in Ukraine]. Natsionalna akademiia derzhavnoho upravlinnia pry Prezydentovi Ukrainy Dnipropetrovskyi rehionalnyi instytut derzhavnoho upravlinnia - National Academy of Public Administration under the President of Ukraine Dnipropetrovsk Regional Institute of Public Administration, 1(12). Retrieved from http://www.dridu.dp.ua/vidavnictvo/2012/2012_01(12)/12nooovu.pdf [in Ukrainian].

3. Zakon Ukrainy "Pro dobrovilne obiednannia terytorialnykh hromad" : vid 5 liutoho 2015 r., № 157-VIII [Law of Ukraine "On voluntary association of territorial communities" from February 5, 2015, № 157-VIII]. zakon.rada.gov.ua. Retrieved from http://zakon4.rada.gov.ua/laws/show/157-19 [in Ukrainian]. 
4. Zakon Ukrainy "Pro mistseve samovriaduvannia v Ukraini" : vid 21 travnia 1997 r., № 280/97VR [Law of Ukraine "On local self-government in Ukraine" from May 21, 1997, № 280/97BP]. zakon.rada.gov.ua. Retrieved from http://zakon4.rada.gov.ua/laws/show/280/97vr [in Ukrainian].

5. Torhonska, A.V. (2017). Reformuvannia orhaniv mistsevoho samovriaduvannia v Ukraini [Reforming bodies of local self-government in Ukraine]. Pravo $i$ suspilstvo - Law and Society, 1(2), 42-47 [in Ukrainian]. 